INTRANSITIVE ENCOUNTER 



\section{Intransitive Encounter}

SINO-U.S. LITERATURES AND THE LIMITS

OF EXCHANGE

Nan Z. Da

Columbia University Press

New York 


\author{
Columbia University Press \\ Publishers Since 1893 \\ New York Chichester, West Sussex \\ cup.columbia.edu \\ Copyright (๑) 2018 Columbia University Press \\ All rights reserved \\ Library of Congress Cataloging-in-Publication Data \\ Names: Da, Nan Z., author.
}

Title: Intransitive encounter : Sino-U.S. literatures and the limits of exchange / Nan Z. Da.

Other titles: Sino-U.S. literatures and the limits of exchange

Description: New York : Columbia University Press, 2018. | Includes bibliographical references and index.

Identifiers: LCCN 2018016138 (print) | LCCN 2018040186 (ebook) | ISBN 9780231547628

(electronic) | ISBN 9780231188029 (cloth : alk. paper) | ISBN 9780231188036 (pbk.)

Subjects: LCSH: American literature-19th century-History and criticism. |

American literature-Chinese influences. | United States-Relations-China. |

Chinese literature -19 th century-History and criticism. | Chinese literature-American influences. | China-Relations-United States. | Culture in literature.

Classification: LCC PS159.C5 (ebook) | LCC PS159.C5 D3 2018 (print) | DDC 810.9/o03-dc23

LC record available at https://lccn.loc.gov/2018016138

Columbia University Press books are printed on permanent and durable acid-free paper.

Printed in the United States of America

Cover design: Milenda Nan Ok Lee

Cover art: Chen Qi, “Dreaming of Butterfly, No. 1, 2000 陈琦, “梦蝶之一” (木板水印), water-based woodblock print. 
For Michael Segal and Bill Quinn 
